Ks. Czesław BARTNIK

(Lublin, KUL)

\title{
NAUKA LEONA WIELKIEGO O PRYMACIE BISKUPA RZYMU
}

Nauka św. Leona Wielkiego, papieża w latach 440-461, jest wręcz mistrzowska i może być przyjmowana bez korekty i dzisiaj, a nawet jest dużo głębsza i bardziej systemowa, niż współczesne ujęcia prymatu.

1. Źródła Leonowej nauki. W tym panelowym wystąpieniu muszę pominąć omówienie pism Leona, a mianowicie jego Mów vel Traktatów (w liczbie 97, zwłaszcza od 1 do 6 oraz od 82 do 84 , w doskonałym wydaniu krytycznym A. Chavasse'a) ${ }^{1}, 143$ Listów również w większości w wydaniach krytycznych $^{2}$, być może i innych fragmentów Leonowych, jak np. z Sacramentarium Leonianum $^{3}$, jak też pomijam całą odpowiednią semantykę działań i dyplomacji Papieża. Omawiam to wszystko względnie obszernie w pracach: Teologia historii wedtug Leona Wielkiego ${ }^{4}$ i Nadzieje upadajacego Rzymu. Papieska wizja świata ze schytku Imperium Rzymskiego ${ }^{5}$. Tutaj chodzi mi jedynie o źródła, z których korzystał sam Leon Wielki ${ }^{6}$.

Leon był Toskańczykiem, urodził się zapewne ok. roku 385, ale już od wczesnej młodości przebywał w Rzymie. Tutaj występuje w roku 418 jako akolita, w roku 422 jako diakon, a w 440 jako diakon zostaje wybrany na papieża 29 września. W rezultacie poglądy Papieża ukształtowały się w niszy ośrodka rzymskiego, który posiadał długą i rozwiniętą tradycję, także intelektualną i doktrynalną, a którą on sam nazywał „Roma magistra" ${ }^{\text {, }}$ co trzeba

${ }^{1}$ Por. Sancti Leonis Magni Tractatus septem et nonaginta, ed. A. Chavasse, CCL 138-138A, Turnholti 1973; inne wcześniejsze: ed. R. Dolle, SCh 22, 49, 74, 200 lub PL 54, 141-468 (ed. Ballerini).

2 Por. PL 54, 593-1218 (ed. Ballerini).

${ }^{3}$ Por. PL 55, 21-158 (Liber sacramentorum Ecclesiae Romanae), lub ed. L.C. Mohlberg, Roma 1956.

${ }^{4}$ Lublin $1972,2001^{2}$.

5 Warszawa 1982, Lublin 2002.

6 Opracowań nauki Leona o prymacie jest zbyt wiele, żeby je można było tu przytaczać.

7 Por. Sermo 82, 1, CCL 138A, 508. 
odnieść zarówno do nauk świeckich, jak i kościelnych. W owym czasie można mówić o pewnej także kościelnej szkole rzymskiej ${ }^{8}$, choć ta - jak zresztą do dziś - musiała pozostawać w głębokim cieniu wobec Urzędu Piotrowego. A zresztą i na papieży do dzisiaj nie wybiera się wielkich uczonych. Wystarczy zatem, że wówczas była duża biblioteka $\mathrm{z}$ archiwum, kuria papieska oraz różne szkoły publiczne, bodajże w milionowym Mieście, liczącym też ok. 100 prezbiterów, często pochodzących też ze Wschodu.

W naszym temacie przede wszystkim żyła rozwijająca się świadomość prymatu władzy w Kościele, w wyniku badań, choć bardzo wiele źródeł zaginęło, od Aniceta (155-166), wyraźniej od Wiktora I (189-199), a najwyraźniej od Damazego I (366-384). W każdym razie papieze po Damazym: Syrycjusz, Anastazy I, Innocenty I, Zozym, Bonifacy I, Celestyn I i Sykstus III mają naukę o prymacie w pełni ukształtowaną, choć $\mathrm{z}$ kolei Leon I osiągnął pełnię tej nauki, tak jak ją zdogmatyzowało Vaticanum I, i jaka funkcjonuje do dziś.

Sam Leon mówi, że jego i ośrodka rzymskiego nauka o prymacie wywodzi

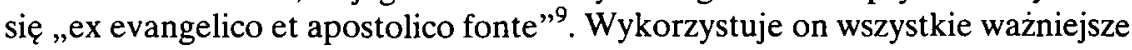
teksty $z$ Biblii, a zwłaszcza tekst obietnicy prymatu (Mt 10,15-19), tekst obietnicy umacniania braci w wierze (Lk 22,31-32) oraz tekst nadania prymatu ( $\mathrm{J} 21,15-17)$, a następnie korzysta, nieraz prawie dosłownie, $\mathrm{z}$ tekstów swoich poprzedników, nazywanych również „apostolskimi”. Była wówczas rozwinięta świadomość, że Urząd św. Piotra kontynuuje bezpośrednio Urząd Apostolski, a więc i Kościół Rzymu jest Kościołem apostolskim.

2. Boskie pochodzenie prymatu. W owych czasach funkcjonowały w jakimś rozmiarze różne opinie na temat pochodzenia prymatu. Według jednych, głównie wschodnich (orientales), prymat jest pochodzenia państwowego, a mianowicie wywodzi się ze znaczenia miasta Rzymu jako stolicy Imperium i od władzy cesarza. Stąd gdy jest przeniesiona gdzieś stolica cesarstwa, to powinien też zostać przeniesiony prymat na biskupa tego nowego miejsca. $\mathrm{Na}$ Zachodzie niektórzy kult Piotra i prymat kojarzyli z rzymskim kultem Romulusa, założyciela Miasta, którego święto obchodzono właśnie 29 czerwca. Byli i tacy, którzy uczyli, że życie Kościoła powinno iść za biegiem słońca, a więc ma swoje źródło na Wschodzie, bo Chrystus jest słońcem Kościoła, a więc pierwszym Kościołem mógłby być albo Jerozolimski jako Mater Ecclesiarum, albo Antiocheński, albo nawet i Aleksandryjski. Według najstarszej tradycji, glównie u autorów zachodnich (occidentales), prymat jest pochodzenia boskiego, a mianowicie został ustanowiony przez Chrystusa, przekazany Apostołowi

${ }^{8}$ Por. moją rozprawę: Gnozeologia teologiczna w drugiej szkole rzymskiej, RTK 25 (1978) 2. 2, 55-71.

${ }_{9}$ Epistula 162, 3, w: Textus et Documenta (= TD) 20, ed. C. Silva-Tarouca, Roma 1932-1935, s. 167 , w. 78 , por. PL 54, 1145 B. 
Piotrowi jako głowie Kolegium Apostolskiego z poleceniem kontynuacji aż do końca świata.

Chrystus nie ustanowił prymatu w całkowitym oderwaniu od historii, lecz przygotował dla niego grunt na dwa sposoby: na sposób bliższy przez historię biblijną i na sposób dalszy przez dzieje Państwa Rzymskiego. Tak uczy Leon: źródłem prymatu jest Jezus Chrystus, ale najpierw posłużył się pewnymi prefigurami: Abrahamem, który „uwierzył w Boga”, jak i Piotr uwierzył w Bóstwo Jezusa, Mojżeszem, który wywiódł lud swój z niewoli historycznej, a następnie i postacią arcykapłana Sanhedrynu Świętego Miasta Jeruzalem. Według Leona sam Chrystus jest Skałą na pustyni i Kamieniem węgielnym budowy Kościoła, ale i św. Piotr został dopuszczony do uczestnictwa w tej roli, a następnie do jej kontynuacji w historii aż do końca świata:

„Owa moc, którą z Opoki - Chrystusa sam opoką uczyniony, otrzymał, przechodzi na jego spadkobierców"10.

Leon uwzględnia więc przy tym w pewien sposób naukę wschodnich, że prymat łączy się, choć wtórnie, i z historią świecką. Otóż Opatrzność Boża przygotowała niszę dla prymatu kościelnego przez odpowiednie kierowanie historią doczesną. Chrystus, Pan dziejów, tak kierował historią, że doprowadzil do powstania Imperium Rzymskiego jako „auctor et rector imperii”, w tym do zaistnienia Miasta Rzymu jako Glowy świata i do ukształtowania się wladzy cesarskiej, która przygotowała mentalność ówczesnego świata do oddawania posłuszeństwa w stosunku do jednej osoby najwyższej. Krótko mówiąc, według Leona, cały Rzym pogański stanowił drugie po dziejach Narodu izraelskiego historyczne praeparatio Ecclesiae.

„Dobry Bóg, sprawiedliwy i wszechmocny tym większą ujawnił milość ludzkości, że zesłał im "Słowo" równe i współwieczne sobie. „Ciałem stające się Slowo" (J 1, 14) tak połączyło boską swoją naturę z ludzką, że tym zstąpieniem do najgłębszych nizin nas w niebotyczne dźwignęło wyżyny. Aby zaś rozprowadzić działanie tej niewyslowionej łaski po całym świecie, pozwoliła Opatrzność Boża powstać i tak rozróśc się Imperium Rzymskiemu, że graniczyło ono po sąsiedzku z krajami wszystkich narodow. Bożym planom odpowiadało to najbardziej, że mnóstwo państw zrzeszyło się pod jedną władzą (multa regna uno confoederarentur imperio). Przepowiadanie odkupienia mogło szybko i łatwo dotrzeć do narodów (populi), związanych władzą jednego państwa i Miasta (unius regimine civitatis) ${ }^{11}$.

Tak to i Rzym wypełnia plany Boże. Biblijne światło Objawienia zostaje osadzone na świeczniku rzymskim, krzyż Chrystusa staje na szczycie Rzymu, a Piotr zasiada na postumencie Romulusa:

${ }^{10}$ Sermo 5, 4, CCL 138, thum. K. Tomczak, POK 24, 20.

11 Sermo 82, 2, CCL 138A, 510-511, POK 24, 389. W pozostałych cytatach przekład autora. 
„[...] trofeum krzyża Chrystusowego miałeś, Piotrze, zatknąć na szczytach, rzymskich, dokąd zgodnie z zaplanowanymi boskimi ekonomiami uprzedzały cię $\mathrm{i}$ honor władzy i chwała męki"12.

Ten sam Chrystus, Pan historii, który uczynił z Rzymu szczyt świata, osadził na tym szczycie Piotra:

„Bo gdy dwunastu Apostołów, przyjąwszy za sprawą Ducha Świętego zdolność mówienia wszystkimi językami, podjęlo się dzieła wszczepienia światu Ewangelii po rozdzieleniu sobie krajów, to najbardziej błogosławiony Piotr, książę apostolskiego ordo, został przeznaczony do szczytu Rzymskiego Imperium, aby swiatto prawdy, objawione dla zbawienia wszystkich ludów, skutecznie rozlewało się od samej głowy na cale ciało świata"13.

I tak Rzym pogański przekształcił się w Rzym Piotrowy - z pełnego ustanowienia Chrystusa i natchnienia Ducha Swiętego.

3. Natura prymatu Piotrowego. W początkach Kościoła byl problem, czy podmiotem prymatu jest cała gmina rzymska, która jest reprezentowana przez biskupa (por. List Pawłowy do Rzymian), czy tylko sam biskup Rzymu, który jest głową gminy rzymskiej. Otóż w tradycji samego papiestwa panowała świadomość, że bezpośrednim podmiotem prymatu jest przełożony gminy, czyli biskup Rzymu. Kościół Rzymu określano jako Sedes Petri, Sedes principis apostolorum. Leon podkreślał to bardzo mocno:

,$[\ldots] \mathrm{z}$ całego świata jeden Piotr zostaje wybrany, aby przewodzil powołaniu wszystkich narodów (vocationi universarum gentium)"14.

Niemniej zgodnie $\mathrm{z}$ rzymską zasadą wiązania łaski $\mathrm{z}$ naturą - Leon nie odrywa biskupa od swego Kościoła. Toteż i cały Kościół rzymski ma szczególny udział w autentycznej wierze, nauce i miłości chrześcijańskiej, przewodzi innym Kościołom, jest szczególnie wybrany, kapłański, królewski i święty, jest i pozostanie bez błędu i herezji:

„Albowiem choć każdy Kościół, jaki tylko jest na całym kręgu ziemi, powinien rozkwitać wszystkimi cnotami, to jednak wy szczególnie musicie wybiegać ponad ludy zasługami pobożności, gdyż was jako opartych na samym fundamencie apostolskiej Skały Pan nasz, Jezus Chrystus razem ze wszystkimi odkupił, ale blogosławiony Piotr przed wszystkimi wprowadził w chrześcijaństwo"15.

\footnotetext{
12 Sermo 82, 5, CCL 138A, 515, w. 124-126.

13 Sermo 82, 3, CCL 138A, 511-512.

14 Sermo 4, 2, CCL 138, 18, w. 47-48.

15 Sermo 3, 4, CCL 138, 14-15, w. 111-116.
} 
Był też problem sekwencji władzy prymacjalnej między Kościołem w ogóle, Apostołami i samym Piotrem, a mianowicie: czy Chrystus dał władzę bezpośrednio całemu Kościołowi lub/i całemu Kolegium Apostolskiemu, a przez nie dopiero Piotrowi, czy odwrotnie: najpierw i przede wszystkim samemu Piotrowi, a przez niego dopiero Apostołom i całemu Kościołowi. Otóż tradycja rzymska opowiadała się za drugą opinią. Wyraził to już wcześniej papież Syrycjusz (384-399): „przez Piotra otrzymał początek w Chrystusie i apostolat i episkopat" ${ }^{16}$, ale najpełniej oddał to Leon:

„I właśnie z całego świata zostaje wybrany jeden Piotr na przełożonego zarówno powołaniu wszystkich narodów, jak i wszystkim Apostołom i wszystkim Ojcom Kościoła: aby mimo wielu w ludzie Bożym kapłanów i wielu pasterzy, wszystkimi rządził Piotr w sposób właściwy, choć wszystkimi rządzi zasadniczo (principaliter) i Chrystus"17.

Przez Piotra przepływają w misteryjny sposób wszystkie moce zbawienia do całej ludzkości: „nic nie przechodzi na nikogo od Chrystusa bez współudziału Piotra" (nihil sine ipsius participatione transierit) ${ }^{18}$ : per Christum Petro tribuitur, per Petrum apostolis conferatur ${ }^{19}$. Chrystus „umiescil sakrament zasadniczo (principaliter) w Piotrze jako najwyższym spośród wszystkich Apostołów, i zechcial, żeby od niego jakoby jakiejś głowy (quasi quodam capite) dary Chrystusowe spływały na całe ciało" 20 . Przy tym Leon tłumaczy oryginalnie, że zaparcie się Piotra nie było ustaniem wiary w Bóstwo Jezusa, lecz tylko brakiem męstwa. I z tego zdarzenia wypłynęła nauka, że nie należy polegać na sobie, lecz na łasce i Chrystusie. Ponadto zdarzenie to stało się, zdaniem Leona, okazją ustanowienia sakramentu pokuty ${ }^{21}$.

Władza prymacjalna nie jest władzą jedynie nad biskupami i nad innymi urzędami w Kościele lub na wydzielonych obszarach, lecz jest to władza bezpośrednia nad wszystkimi i we wszystkich sprawach (in omnibus causis) ${ }^{22}$, choć praktycznie do papieża odnoszone są sprawy najważniejsze (causae maiores) ${ }^{23}$. Leon określa ten powszechny zakres jako plenitudo potestatis ${ }^{24}$.

Nie jest to władza jedynie honorowa lub czysto administracyjna czy dyscyplinarna albo też tylko jurydyczna: jest to władza personalistyczna, ma charak-

16 Epistula 5, 1, PL 13, $1155 \mathrm{C}$.

17 Sermo 4, 2, CCL 138, 18, w. 47-51; por. Sermo 5, 2, CCL 138, 23, w. 31.

18 Sermo 4, 2, CCL 138, 17, w.40-41.

19 Sermo 4, 3, CCL 138, 20, w. 103-104..

${ }^{20}$ Epistula 10, 1, PL 54, 629A; por. Epistula 120 TD 20, s. 169, w. 15; Sermo 63, 6, CCL 138A, 386.

${ }^{21}$ Por. Sermo 60, 4.

22 Por. Innocentius, Epistula 13, 1, PL 20, 515

23 Por. tenże, Epistula 2, 3-6 PL 20, 472A-473A.

24 Por. Epistula 14, PL 54, 671B: ,in partem sis vocatus sollicitudinis [Anastasius episcopus Thessalonicensis], non in plenitudinem potestatis". 
ter relacji międzyosobowych, wywodzi się z samego wcielenia Słowa Bożego i ma walor zbawczy, oparty na wierze w Bóstwo Jezusa: „Ty jesteś Mesjasz, Syn Boga Żywego" (Mt 16,16). Jest „kluczem do nieba” - stąd Piotr „Klucznik” (claviger) $^{25}$. Kto jest poza władzą Piotra, jest poza Ciałem Chrystusa ${ }^{26}$. W ten sposób Leon mówi o swoistej prymacjalnej ekonomii zbawienia: Pontificii sacramentum $^{27}$.

4. Rekapitulacja petrynistyczna. W spoleczeństwie Miasta Rzymu rozwijała się wówczas nauka, że Rzym jest głową świata, a świat jest jednym „ciałem”, należącym do tej głowy. W aspekcie kościelnym świadczy o tym choćby papież Bonifacy I (418-422):

„Jest pewne, że Kościół Rzymu jest niejako głową dla Kościolów rozproszonych po całym świecie, a stanowiących jego członki; ktokolwiek się od glowy oderwie, staje się pozbawiony religii chrześcijańskiej, gdyż nie oparł się w swym bytowaniu na tym samym organizmie"28.

Leon naukę tę dopełnia i rolę Piotra jako głowy rozciąga także na dzieje świata i na historię doczesną. Piotr jest widzialną głową (caput) całego Ciała Kościoła na ziemi i przez to rekapituluje w sobie dzieje zbawienia na ziemi, a w konsekwencji jest także kimś decydującym i o dziejach świeckich. Jest bowiem opoką tej budowli, której bramy piekielne nigdy nie przemogą:

"Chrystus zechcial, żeby od Piotra jakoby jakiejs glowy (quasi quodam capite) dary Chrystusowe spływały na cale ciało”29. „Najbardziej błogosławiony Piotr, książę apostolskiego urzędu, został przeznaczony do szczytu Rzymskiego Imperium, aby światło prawdy, objawione dla zbawienia wszystkich ludów, skuteczniej rozlewało się od samej glowy na cale ciało"30.

A zatem prymat Piotrowy, stając się opoką chrześcijaństwa, tym samym okazuje się głównym i niezwyciężonym czynnikiem dziejów świata.

I tak w Rzymie Piotrowym wypełnia się posłannictwo Rzymu do całego świata i do całej historii ludzkiej.

„Przez świętą stolicę blogosławionego Piotra szerzej przewodzisz, Rzymie, boską religią, niż panowaniem ziemskim"3!

\footnotetext{
${ }^{25}$ Por. Sermo 49, 3, CCL 138, 288, w. 75.

26 Por. Epistula 10, 1, PL 54, 629A.

27 Por. Sermo 4, 1, CCL 138, 17, w. 29; zob. też Sermones 3, 3; 4, 1-4; 5, 2-4 i inne.

28 Epistula 14, 1, PL 20, 777AB.

${ }^{29}$ Epistula 10, 1, PL 54, 629A; por. Epistula 120, TD 20, s. 169, w. 15; Sermo 63, 6.

30 Sermo 82, 3, CCL 138A, 512, w. 69-72.

31 Sermo 82, 1, CCL 138A, 509, w. 26-27.
} 
Orbis romanus poszerzył się na orbis christianus, a przez niego już na cały świat: na totus orbis terrarum, na universus mundus ${ }^{32}$.

Prymat Piotrowy jest przede wszystkim darem Chrystusa dla osiągnięcia tego, co jest dla ludzkości na ziemi najistotniejsze, a mianowicie powszechnej jedności. Sekwencja jest u Leona następująca: prymat Piotrowy jest zwornikiem jedności Kościoła (i Kościołów lokalnych), a jeden Kościół powszechny jest - i będzie - zwornikiem jedności rodzaju ludzkiego i całego świata. Głównym więc zadaniem chrześcijan katolickich jest przełamywanie podziałów, partykularyzmów i wszelkiego rozbicia, które są dziełem diabła i grzechu. Dlatego zaś Leon został nazwany „doktorem jedności”.

Kościół jest - i ma być - „narodem ze wszystkich ludów”33. Stąd i prymat i całe chrześcijaństwo musi się ustawiać pozytywnie i misyjnie do świata barbarzyńców. Ciekawe, że Leon milczy absolutnie o arianizmie większości ówczesnych barbarzyńców. Niewątpliwie miał nadzieje na ich szybkie przejście na katolicyzm. Zwracał się osobiście do osobistości ariańskich, które trzęsły wówczas cesarstwem, a mianowicie do Ricimera, Sweba na Zachodzie i do Flawiusza Ardabura Aspara, Alana na Wschodzie - o pomoc dla Kościoła przeciwko monofizytyzmowi ${ }^{34}$. Ponadto w Liście 113 z 453 r. pisal, że dużo bardziej trapi go herezja monofizytyzmu na Wschodzie, niż najazd (Attyli) na Rzym ${ }^{35}$. Zresztą w czasach rozpadu cesarstwa zachodniego papież Leon Wielki stawał się niekwestionowanym przywódcą całego świata zachodniego, nie tylko duchowym, ale i politycznym.

Prudencjusz z Hiszpanii widział jedność świata w podstawach geograficznych: jedna ziemia, jedno niebo, jeden ocean. Ambroży widział podstawę jedności ludzkiej w jednym państwie światowym, Augustyn - w jedności Civitas Dei, cesarze oraz teologowie wschodni - w jedności władzy cesarskiej na świecie, a Leon Wielki widział zaczyn organicznej jedności świata w społeczności zbudowanej na Skale Piotrowej: civitas Dei supra petram: „w mocy tej Opoki, na której jest budowana Civitas Dei" ${ }^{36}$ Jedność ludzkości to jedność religii i Kościoła. I wtedy dopiero może powstać na ziemi jedno królestwo:

„Tak w sobie, Chryste, wszystko wykonałes, żeby jak w miejsce wszelkich żertw składana była jedna ofiara, tak ze wszystkich ludów i narodów żeby stało się jedno królestwo"37.

${ }^{32}$ Por. Sermones 82; 40, 2-5; Epistula 164, TD 20, s. 162 w. 62n.

33 Sermo 9, 2, CCL 138, 34, w. 39.

34 Por. Epistula 150, TD 20, s. 156, w. 35; Epistula 151, tamże, s. 157, w. 8; Epistula 153, tamże, s. 159 n, w. 9.

${ }^{35}$ Por. ACO II 4, s. 65, w. 1-18.

36 Epistula 162, TD 20, s. 165, w. 19.

37 Sermo 59, 7, CCL 138A, 359, w. 185-190 lub PL 54, 341C. 
Jak naród rzymski był narodem złożonym ze wszystkich ludów i narodów (populus gentium), tak i Kościół ma być Kościolem wszystkich ludów i narodów - Ecclesia gentium et nationum ${ }^{38}$.

Dla Leona Jerozolima nie odgrywa już większej roli. Zresztą Chrystus umarł poza nią, Żydzi Go nie przyjęli, a religia żydowska straciła swoją misję i upadła. Obecnie centrum religii i świata stanowi Rzym. Dzięki Urzędowi Piotra Miasto Rzym stało się głową świata w pełnym i najwłaściwszym znaczeniu: per sacram beati Petri sedem Roma caput orbis effecta ${ }^{39}$.

5. Piotr i Paweł. Rzym pogański został zbudowany - według legendy - na Romulusie i Remusie, a Rzym chrześcijański - faktycznie - na Piotrze i Pawle. W teologicznym traktowaniu o Rzymie nie można było tej pewnej paraleli pominąć. Legenda o Romulusie i Remusie przyjęła się już w IV wieku przed Chrystusem. Przy tym specjalnie czczono Romulusa jako zalożyciela Miasta i państwa, a jego święto obchodzono 29 czerwca. $Z$ drugiej strony od IV wieku po Chr. zaczął się rozwijać nadzwyczajny kult Piotra i Pawła, głównie Piotra, jako założyciela Rzymu chrześcijańskiego, a jego święto wyznaczono również na 29 czerwca.

Leon, rozwijając teologię Rzymu Piotrowego w czasie, kiedy jeszcze nie cały Rzym był chrześcijański, nie mógł nie nawiązać do legendy o Romulusie i Remusie. Swięty Augustyn dostrzegał raczej paralelizm między Romulusem i Remusem a Kainem i Ablem. U Leona natomiast założyciele Rzymu kojarzyli się raczej z Piotrem i Pawłem. Oto Romulus i Remus są protoplastami brutalnego Rzymu doczesnego, Piotr i Paweł (consorte Paulo) założyli Rzym laski i ducha. Tamci położyli fundamenty materialne, ci zaś stali się skałą wieczną. Tamci rozpoczęli historię grzechu, podbojów i wojen, ci zapoczątkowali historię cnót i pokoju, ustawiając Miasto na drodze do królestwa Bożego (regnis coelestibus inserendam). Tamci sprowadzili swych potomków na manowce pogańskich błędów, ci są ojcami świętymi, pasterzami prawdziwymi, nauczycielami prawdy zbawczej. Tamci, przede wszystkim Romulus, nadał Miastu imię doczesne, naznaczone piętnem bratobójstwa, ci, przede wszystkim Piotr, nadali mu imię wieczne, czyniąc je ludem wybranym, świętym i kapłańskim. Tamci otoczyli Miasto murami zroszonymi krwią własnego grzechu, ci przez wylanie swojej krwi niewinnej utworzyli naokoło Miasta wraz z naśladującymi ich męczennikami wieniec chwały, olśniewający swym blaskiem wszystkie narody świata. Tamci zakładając Miasto rzucili ziarna przyszłych nieszczęść, ci dokonując odrodzenia ludzkości przywracają stan zbawienia $^{40}$. I dopiero ten chrześcijański Rzym Piotrowy będzie wieczny, a nie Rzym

\footnotetext{
38 Por. Sermo 29, 3, CCL 138, 150 lub PL 54, 229A.

39 Sermo 82, 1, CCL 138A, 509, w. 25-26.

${ }^{40}$ Por. Sermones 82,1 i 6; 84, 1 .
} 
Wergiliusza ${ }^{41}$; ten Rzym daje nadzieję, że przezwycięży wszelkie nieszczęścia, przeciwności i klęski doczesne ${ }^{42}$.

U podstaw wywodów Leona leży, jak się zdaje, doniosłe założenie, że jak Romulus i Remus dokonali związania Miasta - Państwa z ludem pasterskim i rolniczym w jedną całość rzymską, tak Piotr i Paweł przedziwnie zjednoczyli w jeden Kościół rzymski objawioną religię Izraela z ludami pogańskimi. Piotr, choć potem pasterz uniwersalny, to jednak w zasadzie kontynuowal tradycję Narodu wybranego w Kościele, a Pawel, Apostoł pogan był niejako misyjnym biskupem całego świata pogańskiego bez związania z jakąś partykularną diecezją. I w Rzymie, te dwie „połowy” chrześcijańskie, spotkały się razem i związały w jedno. Rzecz znamienna, że taką ideę realizuje dziś Jan Paweł II, który jako stacjonarny biskup Rzymu przyjął na siebie jednocześnie misyjną i wędrowną misję św. Pawła po dzisiejszym poganiejącym świecie; mógłby być śmiało nazwany Piotro-Pawłem. I w tym jest echo jedności Kościoła chrześcijańskiego o dwu tradycjach religijnych i kulturowych.

6. Rzym a Konstantynopol. Leonowa wizja Kościoła i prymatu Piotrowego nie dopuszczała dwu głów lub dwóch centrów władzy. Ujawniło się to bardzo wyraźnie w świetle sporu o 28 kanon Soboru Chalcedońskiego.

Sobór Nicejski z roku 325 mial asystencję Ducha Świętego co do doktryny objawionej, ale nie miał daru proroczego w dziedzinie administracji kościelnej i nieopatrznie zatwierdził instytucję patriarchatów: Antiocheńskiego, Aleksandryjskiego i Rzymskiego ${ }^{43}$. Był to początek podziału Kościoła, a przede wszystkim rozłamu na Kościół Wschodu i Zachodu, co korespondowało nieszczęśliwie $\mathrm{z}$ podziałem cesarstwa rzymskiego na wschodnie i zachodnie. U podstaw tych podziałów leżała doczesna ranga miasta. Błędny akt ujawnił szybko robaczywe owoce: oto synod bizantyjski z roku 381, uznany potem za Sobór Konstantynopolitański I w niszy cesarstwa wschodniego uchwalił słynny kanon 3, który przyznawal biskupowi młodziutkiego, ale cesarskiego miasta Konstantynopola „godność drugiego miejsca” jako biskupowi „Nowego Rzy-

${ }^{41}$ Por. Sermones 3,$2 ; 5,4 ; 82,1$.

42 Por. Sermones 4, 4; 3, 4; 78, 4; 82, 4; Epistulae 61, TD 20, s. 50, w. 29-31; 160, ACO II 4, s. 107, s. 26-30 i inne.

${ }^{43}$ Por. Concilium Nicaenum, can. 6, thum. T. Wnętrzak, w: Dokumenty Soborów Powszechnych. Tekst grecki, laciński, polski, t. 1: (325-787), red. A. Baron - H. Pietras, ŹMT 24, Kraków 2001 (= DSP I), 31-33: „Starożytny zwyczaj niech będzie zachowany w Egipcie, Libii i Pentapolis, zgodnie z którym biskup aleksandryjski posiada władzę nad tymi wszystkimi prowincjami, tak jak i biskupowi Rzymu przysługuje podobny zwyczaj. Podobnie ma się rzecz w odniesieniu do Antiochii $\mathrm{i}$ innych prowincji: niech będzie zachowywane w Kościołach pierwszeństwo wynikające ze starszeństwa. Niech będzie rzeczą całkowicie jasną, że jeśli ktoś zostal biskupem bez aprobaty metropolity, wielki sobór zarządził, że nie może on być biskupem. Lecz gdy wybór został dokonany przez wszystkich, $z$ rozsądkiem i w sposób zgodny z kanonami kościelnymi, a sprzeciwiają mu się dwaj lub trzej z powodów osobistych, wówczas niech obowiązuje postanowienie większości". 
mu” i „miasta cesarskiego" "44. Wprawdzie papieże nie zatwierdzili tego kano$\mathrm{nu}$, ale powrócił on potem w Chalcedonie jako kanon $28, \mathrm{z}$ takim samym żądaniem ${ }^{45}$, nawet mimo tego, że ówczesny biskup Anatoliusz był skrytym monofizytą.

Oczywiście, było to typowe oszustwo. W gruncie rzeczy chodzilo, nie o „drugie miejsce” (Iunior Roma), lecz o uzyskanie pierwszego miejsca, czyli o przeniesienie prymatu Rzymu na Konstantynopol jako na miasto cesarskie i miasto głównego cesarza w Imperium Romanum. Jednocześnie była to haniebna walka o władzę i hegemonię nad Antiochią, Aleksandrią, no i nad „Starym" Rzymem, i o rozciągnięcie władzy biskupa konstantynopolskiego na wszystkie rejony i prowincje Kościoła Wschodniego. Oba kanony nie mogły być zatwierdzone przez papieży $\mathrm{z}$ tych samych względów. Leon, idąc za tradycją rzymską, chciał opierać patriarchaty na miastach związanych nie z władzą cesarską, lub z mitologią geograficzną, lecz z Piotrem; patriarchaty zatem mogły być: w Antiochii, gdzie był Piotr, w Aleksandrii, gdzie biskupem był uczeń Piotra, św. Marek, i w Rzymie, gdzie Piotr poniósł śmierć jako głowa gminy rzymskiej. Po pewnym czasie zgodzono się i na Jerozolimę, gdzie św. Piotr przebywał do czasu rozesłania Apostołów. Nie można się jednak było zgodzić na opieranie patriarchatu na władzy cesarskiej lub królewskiej.

Leon wyłożył tę naukę niezwykle jasno w fakcie odrzucenia kanonu 28 oraz w mocnej polemice $z$ dworem cesarza Marcjana (450-457) i cesarza Leona I (od 457 r.). Papież rozróżnił między porządkiem świeckim a duchowym oraz pomiędzy stolicą apostolską a cesarską. Do cesarza pisał dyplomatycznie, że stolicy konstantynopolskiej nie uwłacza w niczym to, że nie może być apostolską:

„Habeat [...] Constantinopolitana Civitas gloriam suam [...], alia tamen est ratio rerum saecularium alia divinarum [...]. Non dedignetur regiam civitatem quam Anatholius apostolicam facere non potest sedem" 46 .

Papież rozróżnia także między civitas regia a civitas sacerdotalis ${ }^{47}$.

44 Por. Concilium Constantinopolitanum, can. 3, tlum. T. Wnętrzak, DSP I 73: „Biskup Konstantynopola powinien mieć honorowe pierwszeństwo po biskupie Rzymu, ponieważ to miasto jest Nowym Rzymem".

${ }^{45}$ Concilium Chalcedonense, can. 28, thum. T. Wnętrzak, DSP I 251: „potwierdzamy oraz ponawiamy te same decyzje co do przywilejów wielce świętego Kościoła Konstantynopola, Nowego Rzymu. Ojcowie słusznie przyznali przywileje stolicy Starego Rzymu, ponieważ był on miastem cesarza. $\mathrm{Z}$ tego samego powodu stu pięćdziesięciu najczcigodniejszych biskupów uznało, ze najświętsza stolica - Nowy Rzym, zaszczycony pobytem cesarza i senatu i cieszący się takimi samymi przywilejami cywilnymi jak Stary Rzym cesarski, powinien mieć te same przywileje w porządku kościelnym i być na drugim po nim miejscu".

46 Epistula 104, TD 20, s. 93, w. 52-65 lub PL 54, 993C-995A; por. Epistula 107, TD 20, s. 108, w. 12.

${ }^{47}$ Por. Sermones 31,$2 ; 33,3$. 
Przy tym Leon wyraźnie oskarża biskupa Anatoliusza o przerost ambicji, o pychę, próbę naruszenia nadprzyrodzonej jedności Kościoła, o zanegowanie prymatu Rzymu, o podstęp, zakłamanie, no i o herezję monofizycką. Gdyby Leon ustąpił Anatoliuszowi, cały Wschód stałby się do dziś monofizycki. Papież dowodził, że tylko Rzymowi (nie używał nigdy terminu: Vetus Roma lub Iunior Roma) przysługuje atrybut civitas sacerdotalis et regia ${ }^{48}$. Nieco później pisał do biskupa Cyru (jeśli list ten jest autentyczny) polemizując z poglądem, że władza idzie za słońcem, a więc ma być na Wschodzie:

„Slońce przyćmione na Wschodzie chmurami Nestoriusza i Eutychesa, zajaśniało czysto na Zachodzie, gdzie swój najwyższy szczyt znalazło w Piotrze"49.

Leon wypowiedział przy tym nawet swego rodzaju proroctwo w razie uzurpacji tytułu Nowego Rzymu przez Konstantynopol:

„Toteż oprócz owej skały, którą Pan położył jako fundament [Kościoła] nie ostoi się żadna inna budowla. Ten, kto nieopanowanie pożąda tego, co mu się nie należy, utraci i swoją dotychczasową wlasnośč ${ }^{50}$.

Oznacza to zatem, że Kościół Bizancjum zginie.

W rezultacie sprowadzenie prymatu u Leona do samej idei biblijnej, jurydycznej, czy administracyjnej, co robi ogół badaczy, jest wielkim zawężeniem nauki Leona Wielkiego. Papież ten ujmuje prymat jako doktrynę, ideę biblijną, dogmat z powszechnego nauczania, ale przede wszystkim jako kategorię zbawczą, jako „Pontificii sacramentum”, istotną strukturę chrześcijaństwa i jako siłę dziejową. Piotr to pierwsza osoba, która przejęła od Chrystusa funkcję głowy ziemskiej i historycznej oraz stała się zasadą organizującą, jednoczącą, weryfikującą i autentyzującą całość nauczania i życia chrześcijańskiego. W tym sensie podmiot prymatu ma znaczenie chrystologiczne, pneumatologiczne, eklezjalne i duchowe, a w rezultacie historiozbawcze w świecie. Prymat rekapituluje Kościół na ziemi i jego dzieje po Wniebowstąpieniu Jezusa Chrystusa.

${ }^{48}$ Por. Sermo 82, 1, CCL 138A, 509, w. 25.

49 Epistula 120, TD 20, s. 170, w. 41-43 lub OL 54, 1049B.

50 Epistula 104, TD 20, s. 95, w. 60n lub PL 54, 995A. 


\section{DIE LEHRE LEON DES GROSSEN ÜBER VORHERRSCHAFT DES PAPSTES}

\section{(Zusammenfassung)}

Leon I. der Grosse, der Papst in den Jahren 440-461, entwickelte die Lehre des römischen Zentrums über Vorherrschaft zum höchsten Grad nicht nur im Gesichtspunkt der Geschichte, der Verwaltung und Jurisdiktion, aber vor allem der Theologie. Laut dieser Theologie kommt die Vorherrschaft aus der Bibel - von Christus hervor. Christus, der Herr der Geschichte bereitete auch den historischen Boden für die Vorherrschaft vor und für die ganze Kirche in der Form des Imperium Romanum, der Stadt Rom und auch des Amts des Cäsars. Die Vorherrschaft ist daher die Machtfülle (plenitudo potestatis), sie bildet die Hauptströmmung der Ökonomie Gottes auf der Erde (Pontificii sacramentum). Durch den Apostolischen Stuhl durchfliesst die Hauptströmmung der Erlösung der Welt (quasi caput mundi). Er ist das Fundamentum und Quelle aller anderen Ämter und Gnaden: per Petrum Apostolis et universae Ecclesiae und ist endlich der Schlüssel der Einheit der Kiche und Menschheit, und dadurch Garant der ewigen Dauer des Christentums. Die Kirchen, vom Petrus abgefallen, gehen zugrunde. 